\title{
Nevrokirurgi ved hjerneslag kan redde liv
}

Forbigående åpning av skalletaket bedret overlevelsen etter hjerneslag med intrakranial trykkstigning, men pasientenes funksjonsnivå et halvt år senere var dårlig.

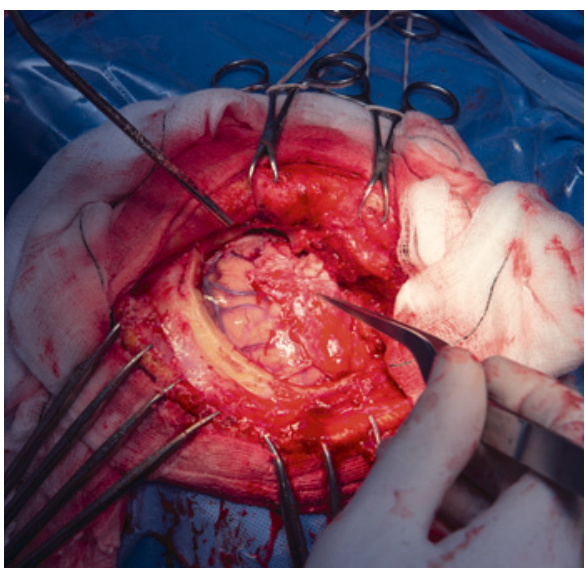

Illustrasjonsfoto: Sciencephoto/NTB scanpix
Iskemisk infarkt $\mathrm{i}$ a. cerebri media kan utvikle seg til malignt hjerneinfarkt med et hjerneødem som forskyver deler av hjernen nedover mot det store nakkehullet og truer vitale hjernestammefunksjoner, såkalt herniering. I en nylig publisert studie ble om lag 100 pasienter over 61 år med denne type hjerneslag randomisert til enten konservativ behandling eller nevrokirugi innen 48 timer fra symptomdebut (1). Den konservative behandlingen besto i osmoterapi, som får hjernecellene til å krympe, eller til ventilasjonsstrategier som bedrer den intrakraniale plassen ved å få blodårene til å trekke seg sammen. Det nevrokirurgiske inngrepet besto av dekompressiv hemikraniektomi, dvs. en forbigående trykkavlastende fjerning av skalletaket med tilhørende duraplastikk.

Overlevelsen etter nevrokirurgi var vesentlig bedre enn overlevelsen etter konservativ behandling. Henholdsvis $38 \%$ og $18 \%$ var i live seks måneder etter og hadde bedre funksjonsnivå. Men også de opererte hadde betydelige sekveler, med Rankin-skår $>3$.

- Dette er en imponerende studie gjennomført $\mathrm{i}$ aldersgruppen der det er hyppigst forekomst av iskemisk hjerneslag, sier seksjonsoverlege Ole Morten Rønning ved Nevroklinikken, Akershus universitetssykehus. - Studien viser at kirurgisk intervensjon øker sannsynligheten for å overleve hos eldre pasienter med malignt hjerneinfarkt, noe som tidligere er vist for yngre pasienter, sier han.

- Også de som ble operert, hadde lavt funksjonsnivå seks måneder senere. Derfor bør man være tilbakeholden med kirurgisk behandling til pasienter i denne aldersgruppen. Et nevrokirurgisk inngrep bør eventuelt bare gjøres etter samtykke fra familie og om mulig pasient, og de samtykkende må være særdeles godt informert, sier Rønning.

\section{Paal H.H. Lindenskov}

Akuttklinikken

Avdeling for anestesiologi

Oslo universitetssykehus, Rikshospitalet

\section{Litteratur}

1. Jüttler E, Unterberg A, Woitzik J et al. Hemicraniectomy in older patients with extensive middlecerebral-artery stroke. N Engl J Med 2014; 370 $1091-100$

\section{Hvor arvelig er autisme?}

\section{Arvelige faktorer forklarer halvparten av forekomsten av autisme. \\ Det viser en ny svensk studie.}

Over to millioner svenske skolebarn ble mellom 1982 og 2006 inkludert i en stor registerstudie for å anslå familiær forekomst og arvelighet av autisme og autismespektrumforstyrrelser (1). Forskerne fant om lag 14500 barn med autismespektrumforstyrrelser, hvorav om lag 6000 hadde autisme. Den relative risikoen for at søsken, inkludert monozygote og dizygote tvillinger, halvsøsken samt fettere og kusiner til et barn med autisme selv skulle utvikle tilstanden, ble undersøkt ved å sammenlikne gruppen med familiemedlemmer til barn uten autisme.

Genetiske faktorer kan ifølge denne studien forklare omtrent halvparten av forekomsten av autismespektrumforstyrrelser. Søsken til barn med autismespekterforstyrrelse hadde ti ganger høyere risiko for å få en slik tilstand. For halvsøsken og fettere var risikoen henholdsvis tredoblet og doblet.

- Denne studien viser betydelig lavere arvelighet for autismespekterforstyrrelser enn tidligere tvillingstudier har vist, sier lege og postdoktorstipendiat Maj-Britt Posserud ved Psykisk helsevern for barn og unge, Haukeland universitetssykehus. - Styrken ved studien er det store datamaterialet og bruken av et landsdekkende register. Dette gir lavere risiko for at funnene påvirkes av utvelgelse og frafall, som ofte har vært høyt. Det kan forklare hvorfor funnene skiller seg så mye fra funnene i tidligere studier, sier hun.

- Studien er et godt grunnlag for å gi informasjon til foreldre og pårørende om sannsynligheten for at et barn vil kunne utvikle autismespekterforstyrrelser dersom det er andre barn med slike tilstander i slekten, sier Posserud.

\section{Tor Atle Rosness}

Tidsskriftet

\section{Litteratur}

1. Sandin S, Lichtenstein P, Kuja-Halkola R et al. The familial risk of autism. JAMA 2014: 311: 1770-7.

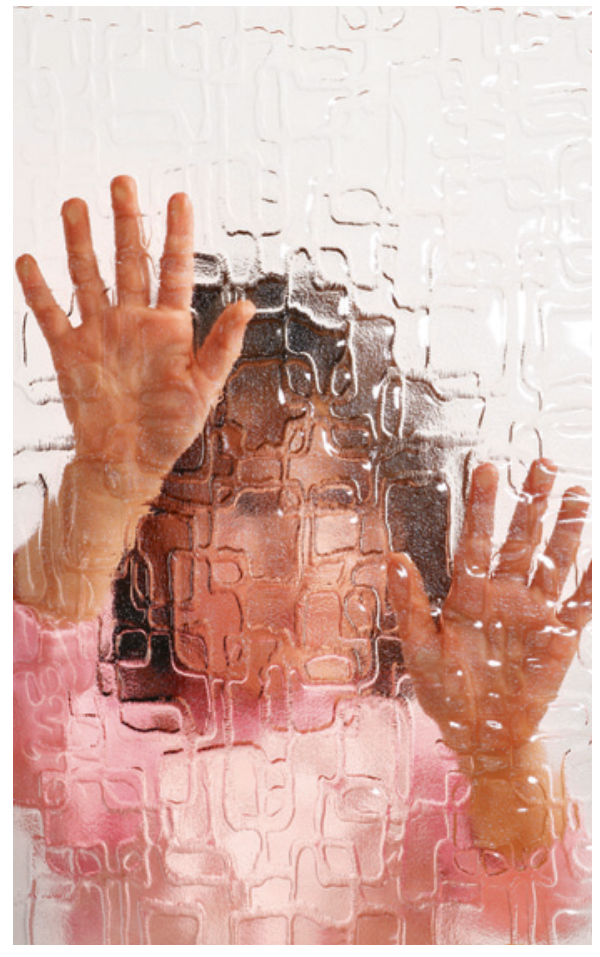

Illustrasjonsfoto: Thinkstockphoto 